\title{
Energy Efficiency and Low Carbon Strategy on Rural Tourism Area: A Case of Mount Annapurna Trekking Route
}

\author{
Prem Subedi $^{1}$, Shree Raj Shakya ${ }^{2}$ \\ ${ }^{1}$ Ministry of Industry, Government of Nepal, Singhadurbar, Kathmandu, Nepal \\ ${ }^{2}$ Center for Energy Studies, Institute of Engineering, Tribhuwan University, Kathmandu, Nepal
}

Email address:

subediprem2014@gmail.com (P. Subedi), subediprem@moi.gov.np (P. Subedi), shreerajshakya@ioe.edu.np (S. R. Shakya), shreerajshakya@gmail.com (S. R. Shakya)

\section{To cite this article:}

Prem Subedi, Shree Raj Shakya. Energy Efficiency and Low Carbon Strategy on Rural Tourism Area: A Case of Mount Annapurna Trekking Route. International Journal of Environmental Protection and Policy. Vol. 4, No. 5, 2016, pp. 133-140. doi: 10.11648/j.ijepp.20160405.14

Received: August 5, 2016; Accepted: August 15, 2016; Published: September 5, 2016

\begin{abstract}
Tourism is one of the major industries in Nepal and rural tourism is an emerging dimension in the country. This paper explores the energy consumption and emission pattern up to 2030 in the commercial sector (Hotel and Lodge) of rural tourism and conservation area. Trekking route of Mount Annapurna base camp (4130 meter) was considered for study. From the household survey of study area total energy consumption in the commercial sector was 5,560 GJ (36.26 GJ/HH) in 2014. Fuel wood was the major source of energy contributing $70.06 \%$ share on total energy and electricity contributes shares of only $13.67 \%$. This shows high dependence on traditional fuels, which result in the degradation of forest engendering the imbalance in fragile ecosystem of conservation area. This study uses Long-range Energy Alternatives Planning System (LEAP) modeling framework to analyze three scenarios of energy system development. First one is the business as usual scenario based on the historical trend and government plans and policies. Second is the clean kitchen scenario where efficient end use technologies are introduced in demand side and the third one is low carbon scenario where clean and renewable energy sources are introduced in supply side. It is found that under business as usual scenario the energy consumption was 5560 GJ and GHG emission was 27.3 tons of carbon dioxide equivalents in 2014 and they are expected to increase by $2.26 \%$ and $1.8 \%$ respectively from 2014 to 2030. The clean kitchen scenario and low carbon scenario analyzed in this study has a significant reduction in energy consumption by 14 percent and 54.5 percent respectively in year 2030. The cumulative energy saving equivalent to the electricity saving value accounts for NRs 213 million and NRs 811.2 million at current price of electricity of Nepal. The average cumulative fuel wood saving was found to be 307 metric tons (1.8 tons per HH) for clean kitchen scenario and 1063 metric tons (6.25 tons per $\mathrm{HH}$ ) for the low carbon scenario. The model output shows emission reduction of 2.24 percent for the clean kitchen scenario and 44.7 percent in low carbon scenario for the year 2030. Government of Nepal and Annapurna Conservation Area Project (ACAP) should formulate and implement policies and strategic planning referring the assumption of clean kitchen and low carbon scenario to reduce dependency on fuel wood for protection of the fragile ecosystem of conservation area and to maintain eco-tourism.
\end{abstract}

Keywords: Energy, Environment, Rural Tourism, Eco-tourism, Low Carbon, Energy Efficiency

\section{Introduction}

In Nepal, residential sector is the major energy consuming sector which accounts $80.4 \%$ share of total energy consumption of 376.3 million GJ [1]. More than $80 \%$ of the country's total households are in rural area [2]. Biomass, mostly fuel wood, dominates larger portion of the energy resource used for cooking in residential sectors whereas energy from hydropower source, fossil fuels, renewable energy technologies (RETs) such as micro-hydropower, solar home system, institutional solar PV system, wind power plant contributes in smaller portion [1]. $78 \%$ of the total countries household relies on traditional biomass for cooking with high capability of pollutant emission [3].

Some of the researchers analyzed the relationship between tourism and energy in different sectors, for example, destination and accommodation [4-7]. They focused on 
energy consumption and efficiency of various sources. Gossling S. (2002) estimates 6\% share of worlds total energy consumption of $14,000 \mathrm{PJ}$ by tourism related activities in tourist accommodation sector and activity sector, remaining on transportation sector [5]. Sanjay K. Nepal (2008) analyzes energy consumption patterns in tourist lodges in Nepal's Annapurna region and identified the need of practical rural energy strategy for rural tourism destination in his research work [8]. Sunlu (2003) in his paper describes the effects of tourism on natural resources, environment pollution and physical environment. The paper suggests that forests often suffer negative impacts of tourism in the form of deforestation caused by fuel wood collection and land clearance. For example, one trekking tourist in Nepal and area already suffering the effects of deforestation can use four to five kilograms of wood a day [9].

This paper is oriented to find the effect on energy and environment due to the introduction of clean energy supply and energy efficient end use devices in commercial sector (hotel and lodge) of high altitude trekking route of Nepal. It considered a trekking route of the Mount fishtail and the Mount Annapurna which passes through the Ghandruk VDC, is famous for village tourism and trekking in the world. A growing tourism industry in Nepal and Ghandruk being a famous tourist destination, the energy demand for local people and tourist is increasing where by affecting the fragile ecosystem of the conservation area. Any man made activity should be limited to protect its environment. This caters the need for cumulative study of energy and environment to maintain eco- tourism ${ }^{1}$. This paper analyzed the energy strategy required to eliminate unsustainable dependence on traditional resources of fuels at the high altitude trekking route.

\section{Literature Review}

Most of the Nepalese people living in rural area use traditional form of energy to fulfill their energy need [10]. The consumption of traditional solid biomass has a negative effect on the quality of lives of the people, since it takes much time to collect wood and causes adverse effects on health. Besides, the use of these traditional energy sources is neither sustainable nor desirable for environmental considerations. Therefore, there is a need to replace or supplement those energy supply system by modern forms of renewable energy. These renewable energy sources are uninterruptible and infinitely available due to their widespread complementary technologies, which can accommodate the country's need of diverse supply. Besides, these energy sources are environmentally friendly as they have very little or no negative impact on greenhouse gases (GHG), landscape, climate, physical and topographical environment [11].

1 Eco-tourism is defined as environmentally and socially responsible tourism which minimizes degradation of natural environment, cultures and socio economic conditions and provides economic benefit to local people through employment and services.
Management of renewable energy sources (RES) has been prioritized in many communities throughout the world since the "energy crisis" of the 1970s [12]. Also, the soaring energy demand, rising energy prices, as well as increasing concerns over environment, health and climate change implications of energy related activities are having significant effects on RES management practices, representing one of the most pressing challenges in the communities [13].

\subsection{Energy Consumption Pattern}

The total energy consumption for the year 2011/2102 is about 376.3 million GJ at national level. Residential sector accounts for the major share of the energy consumption of $80.4 \%$. The overall energy consumption of Nepal is largely dominated by the traditional non commercial forms of energy such as fuel wood, agriculture residue and animal waste. The share of traditional biomass is highest contributing $79.8 \%$ of the total energy consumption. Fuel wood alone contributes $71.1 \%$ of total energy consumption [1].

\subsection{Residential Sector Energy Consumption}

The total energy consumption in residential sector is 302.3 million GJ. There is 269.1 million GJ of energy consumption in the rural residential which is equivalent to $89 \%$ of the total residential energy consumption. Fuel wood alone supplies $83.7 \%$ of the total energy requirement of the residential sector followed by animal waste $(6.3 \%)$, agri residue $(4.4 \%)$ and petroleum $(2.3 \%)$ respectively. The consumption of the fuel wood is high in rural residential constituting about $98.6 \%$ of the total fuel wood consumed in residential sector [1].

The residential sector energy consumption is increasing by $13 \%$ from the year 1995 to 2011. Per capita energy consumption and per capita fuel wood consumption for the year 2011/12 was 14.2 GJ and 10.1 GJ respectively [1, 10, 14]. The per capita fuel wood consumption was about $668 \mathrm{~kg}$ in the year 1995/96 which reduced to a limit of $605 \mathrm{~kg}$ at 2011/2012 [1].

\subsection{Plans and Policies}

\subsubsection{National Plan}

The Fifth Plan (1975-1980) policy statement of the government was the first sector specific policy statement in the energy sector [15]. In the Plan, the government emphasized the need to reduce heavy dependence on traditional source of biomass and imported oil, and increase the supply of renewable energy sources including hydropower to meet the increasing demand for energy. After fifth plan, government had given emphasis on clean energy development, which continued till thirteenth three year plan. Tenth plan introduced the energy subsidy policy and subsidy implementation work plan and brought to implantation within the framework of objectives and policies set for alternative energy sector [16]. Also, tenth plan states plans and policies for the development of rural energy by reducing cost and increasing skilled manpower. The thirteen three year 
plan (2013-2016) states the promotion of small and micro hydro, solar energy, bio-energy, and wind energy development. It states to reduce fuel wood consumption, adaptation of Improved Cook Stove (ICS), Biogas, Gasifier, Bio-briquette and community biogas [17].

To achieve the target of these plans some polices and organizations are established. Rural Energy Policy-2006, Climate change policy, NAPA, LAPA, Renewable energy subsidy policy are some policies and Alternative Energy Promotion Center, Water and Energy commission secretariat are some organization established to work in energy sectors.

\subsubsection{Rural Energy Policy}

The current Rural Energy Policy 2006 has been conceptualized with a sector-wide approach. The policy specifically targets to install improved biomass technologies to meet cooking and other heating energy needs, micro hydro installation for rural electrification through off-grid power production and distribution that is capable to be gridconnected when grid is extended, solar home systems (10 wattpeak and above) and white-led and photovoltaic based solar lights replacing kerosene lamps. The approach of the subsidy policy is to move away from per $\mathrm{kW}$ subsidy to per household subsidy for micro hydro for inclusion. The program of new small solar system based on small photovoltaic and white led as an immediate and intermediate solution will be more affordable to the poor [18]. The policy recognizes solar home system as a mainstream electrification option for many rural areas where grid and micro hydro is not an option for long time to come. The policy does not specify the target share of the rural renewable energy technologies for future years.

Rural energy subsidy policy was formulated with the objective to reduce dependence on traditional and imported energy by increasing access to renewable energy for improving the livelihoods of people and create employment opportunities especially in the rural areas. The key strategies of this policy are to reduce the initial upfront cost thereby increasing the access to the renewable energy services, to maximize service delivery and efficiency in the use of renewable energy resources and technologies in rural areas and to use renewable energy solutions, to support development and growth of the renewable energy market and to encourage public-private sector participation in the renewable energy [19].

\subsection{Energy Models}

Long-range Energy Alternatives Planning System (LEAP) was originally created in 1980 for the Beijer Institute's Kenya Fuel wood Project, to provide a flexible tool for long-range integrated energy planning. LEAP provided a platform for structuring data, creating energy balances, projecting demand and supply scenarios, and evaluating alternative policies, the same basic goals as the current version of LEAP [20]. LEAP can be used for analyzing local to global energy-systems. It functions using an annual time-step, and the time horizon can extend for an unlimited number of years (typically between 20 and 50). LEAP supports a number of different modeling methodologies: on the demand-side these range from bottomup, end-use accounting techniques to top-down macroeconomic modeling. On the supply side, it provides a range of accounting and simulation methodologies for modeling electricity generation and capacity expansion planning. LEAP can simulate all sectors, all technologies, and all costs within an energy-system, as well as externalities for any pollutants, decommissioning costs, and unmet demand costs. LEAP also includes a scenario manager that can be used to describe individual policy measures. The results include fuel demands, costs, unit productions, GHG emissions, air-pollutants, and more. Usually, these results are then used to compare an active policy scenario versus a policy neutral business-as-usual scenario [21].

\subsection{Energy Resources and Their Assessment}

Renewable technologies are becoming increasingly cost competitive in a number of countries and circumstances, but public support schemes are still required to support deployment in many others. Renewable-based power generation capacity is estimated to have increased by 128 GW in 2014 , of which $37 \%$ is wind power, almost one-third solar power and more than a quarter from hydropower. This amounted to more than $45 \%$ of world power generation capacity additions in 2014, consistent with the general upward trend in recent years [22]. The renewable are the primary, domestic and clean or inexhaustible energy resources [11]. To implement new energy technologies, one important factor is the availability of the raw resource used by specific technology. Availability of the energy resources can be identified by visual inspection, from metrological data and maps. After availability, another term to be considered is the theoretical, geographical, economical and technical potential of the available RETs.

\subsubsection{Wind Power}

Solar and Wind Energy Resource Assessment in Nepal (SWERA) report has found that Annapurna Conservation Area Project ACAP area covers $143 \mathrm{sq} \mathrm{km}$ above Wind power density (WPD) of $300 \mathrm{Watt} / \mathrm{m}^{2}$ and with $5 \mathrm{MW}$ plant installed per sq km yields $716 \mathrm{MW}$. But in our study area WPD is less than $300 \mathrm{watt} / \mathrm{m}^{2}$ which is not useful for wind power generation [23].

\subsubsection{Micro-hydro Power}

Micro hydro is a type of hydroelectric power that typically produces up to $100 \mathrm{~kW}$ of electricity using the natural flow of water. These installations can provide power to an isolated home or small community, or are sometimes connected to electric power networks. Variation in altitude and presence of number of rivers and rivulets shows the potential of micro hydro power plants in Ghandruk. Twenty Micro Hydro plant are already installed in Ghandruk VDC with total installed capacity of $361 \mathrm{~kW}$, capacity ranging from $5-50 \mathrm{~kW}[23,24]$. 


\subsubsection{Solar Power}

Solar and Wind Energy Resource Assessment in Nepal (SWERA) report has found the potential of both solar PV and solar water heating system in study area. Solar remote PV potential map shows the solar radiation of 4.5-5.0 $\mathrm{kWh} / \mathrm{m}^{2} /$ day and for solar water heating system area available in kaski is $57.2 \mathrm{Km}^{2}$ with Average Annual Radiation $5.632 \mathrm{kWh} / \mathrm{m}^{2} /$ day [23].

\subsection{Biomass}

Wood as a biomass source is used for cooking and water heating. 22.5 percent of total land area of Ghandruk V.D.C. is forest [24]. Most of the household i.e. 78.24\% rely on government forest to fulfill their energy demands which is an ACAP forest; possibility of forest depletion has been marked [21]. So, energy supply from wood must be reduced to save fragile ecosystem of conservation area.

\subsection{Tourism, Energy and Environment}

Gossling, S.(2002) specified the tourism related energy consumption and divide energy for tourism in transportrelated purposes (travel to, from and at the destination) and destination-related purposes excluding transports (accommodation, food, tourist activities, etc.). Within the destination, energy use can be divided in two broad categories, accommodation' and 'activities' [5]. Energy use in the different types of accommodation includes heating, air conditioning, cooking, operating electric devices, cooling, illumination and cleaning. Tourism related activities like campfire and cultural activities demonstration are very popular in village tourism area of Nepal. Increase in tourism leads to increase in energy demand.

Fuel harvesting and combustion are two major sources of environmental impacts at the household level of energy use. Unsustainable fuel-wood consumption has contributed to depletion of forests in many countries. Similarly, these activities impose significant occupational health hazards, particularly on women and children who are involved in collection and use of household energies [25]. Combustion of household fuels leads to air pollution with global warming implications as well. IPCC provides some information on the GHG emissions from some important household fuels [26]. Low efficiency of many residential energy use technologies results in higher environmental impacts.

Some researchers conducted research in tourism related energy consumption in Annapurna region. Sanjaya K. Nepal (2008) studied tourism-induced rural energy consumption in Annapurna region of Nepal [8]. Study indicates the increasing use of renewable energy and locally developed energy saving technologies. His study concluded that tourism- induced energy demand at rural destination aggravates problems of natural resource conservation at local level and poses a long term threat to the global climate. Also, study emphasize the need of practical rural energy strategy, with long - term goals to eliminate the dependency on wood, and increasing the use of energy efficient technologies for sustainable and sound tourism.

Kamal Rijal (1999) studied the potential benefits, energy price, commercialization, research and development of RET for mountain communities in Hindu Kush region. The study proposes framework for policy recommendations to promote the development of renewable energy resources and technologies to provide broad policy guidelines [27].

\section{Methodology}

\subsection{Data Collection}

For data collection of base year end use demand of energy, questionnaire survey method employed. There are total one hundred and seventy hotels and lodge in the trekking route. Among these thirty samples were taken for survey randomly throughout the route.

For household energy survey, a questionnaire containing four sections was developed including general information, information of household member, household property information and energy consumption information. In general information section household head name, address, caste, religion and family size are noted. In information of household member section education level, occupation and average monthly income are noted. Land holding, number of livestock and house structure are noted in household property information. Energy consumption information section is further divided into five subsections i.e. lighting, cooking, space heating, water boiling and other electric devices. Type of device, number of devices, fuel type, fuel consumption and operation hours are noted in this section.

For energy end uses device used are generally traditional cooking stove, improved cooking stove, kerosene stove, charcoal stove, LPG stove, rice cooker, ceramics heater, fan, kerosene tuki, compact florescent lamp (CFL), incandescent lamp, florescent tube, refrigerator, grinder/mixture, television and radio. Agricultural residue, kerosene, solar, LPG, electricity and fuel woods are the possible energy source available on surveyed area.

Wattage rating of electric devices, energy source and their running time are noted for the devices using electricity and for devices using fuel wood energy, fuel wood consumption in bhari ${ }^{2}$ was noted. Unit used for LPG is number of cylinder ${ }^{3}$ and kerosene in liter. Total consumption for cooking, lighting, water heating and other electric is calculated in gigajoule. To convert energy consumption in gigajoule heating value of wood, kerosene, LPG used are total consumption from fuel wood, kerosene and LPG are converted to gigajoule $(1 \mathrm{GJ}=23.4 \mathrm{~kg}$ of fuel wood or 9.281 of kerosene or 0.2 tanks of a 30-1 LPG) according to published sources [8]. Also, percentage share for each end use in total energy consumption is calculated.

\subsection{Modeling}

2 Bhari is a local unit used to measure fuel wood in residential sector of Nepal, which is approximately equal to $30 \mathrm{~kg}$

3 According to Nepal Oil Corporation, 1 cylinder is equal to $14.2 \mathrm{~kg}$ in average 
To analyze the evolution of energy and environment, a model is developed based on LEAP framework. Energy service demand data collected from household survey is projected up to 2030 considering socio-economic parameter. Energy sources used in the model are wood, LPG, electricity from Micro-hydro and Solar Photovoltaic and solar heat. Energy technologies used to utilize energy are different types of stoves, lighting equipment, solar water heaters and other electric equipment. Cooking, lighting, water heating and other electric equipment are the energy services used in modeling. Energy service demand is forecasted using growth on total GDP and number of tourist arrivals. Finally, technology is selected by energy consumption, share, and efficiency and emission factor. Total energy demand with global and local pollutant emission is calculated at the end. The data generated in data collection is utilized by LEAP software to find the result.

\subsection{Energy Service Demand Projection}

Energy Service Demand is projected considering year 2014 data as a base year data using following equation [28].

$$
\mathrm{ESD}_{\mathrm{t}}=\left(\mathrm{TOT}_{\mathrm{t}} / \mathrm{TOT}_{0}\right)^{\alpha 1, \mathrm{i}} \times\left(\mathrm{GDP}_{\mathrm{t}} / \mathrm{GDP}_{0}\right)^{\alpha 2, \mathrm{i}} \times \mathrm{ESD}_{0}
$$

Where,

$\mathrm{ESD}_{0}=$ Energy service demand at base year;

$\mathrm{ESD}_{\mathrm{t}}=$ Energy service demand at year $\mathrm{t}$;

$\mathrm{GDP}_{0}=$ Total GDP at base year;

$\mathrm{GDP}_{\mathrm{t}}=$ Total GDP at year $\mathrm{t}$;

$\mathrm{TOT}_{0}=$ Tourist arrival for trekking and mountaineering at base year;

$\mathrm{TOT}_{\mathrm{t}}=$ Tourist arrival for trekking and mountaineering at year $\mathrm{t}$;

$\alpha 1, i=$ Population elasticity for end use $i$;

$\alpha 2, \mathrm{i}=$ GDP elasticity for end use $\mathrm{i}$;

Number of tourist arrivals for trekking and mountaineering are projected using exponential growth. Growth of past ten year data is calculated and taken average to find growth rate. Total GDP is projected using regression analysis.

\subsection{Scenario Analysis}

In order to test the robustness of result, all analyses should undergo a scenario analysis. Scenario analysis was conducted to find out change in total energy consumption and Green House Gas (GHG) emission due to change in share of cleaner and efficient device in the demand side and cleaner source in the supply side. For this three scenarios were developed.

\subsubsection{Business as Usual (BAU) Scenario}

The business as usual scenario is the reference scenario in this model. This scenario is based on the historical trend and government plans and policies. In this scenario energy is projected considering growth in total GDP and growth number of tourist arrival for trekking and mountaineering $[29,30]$. The share of different end use, energy source and technology are taken constant over the study period. The total energy consumption and emissions are calculated.

\subsubsection{Clean Kitchen Scenario}

In this scenario, efficient and low pollutant emitting technologies are introduced in demand side. Traditional cooking stoves used for cooking and water heating are gradually replaced by $15 \%$ more efficient Improved Cooking Stoves (ICS) [31]. It is assumed that all traditional stoves are replaced by ICS by 2030 A.D. For lighting the incandescent lamps are totally replaced by two third less energy consuming compact florescent lamp by 2030 A.D. Their effect in energy consumption and emission are compared with other scenarios.

\subsubsection{Low Carbon Scenario}

In Low Carbon scenario, clean and renewable energy sources are introduced in supply side. The traditional energy sources are gradually replaced by recent, clean and efficient sources. Wood, kerosene and LPG are replaced by electricity and solar energy for cooking and water heating. Their effect in energy consumption and emission are compared with other scenarios.

Table 1. Assumed share of different energy sources in different years.

\begin{tabular}{llllll}
\hline $\begin{array}{l}\text { Year/Energy } \\
\text { Source }\end{array}$ & Electricity & $\begin{array}{l}\text { Solar } \\
\text { Heat }\end{array}$ & $\begin{array}{l}\text { Fuel } \\
\text { Wood }\end{array}$ & LPG & Kerosene \\
\hline 2020 & $20 \%$ & $3 \%$ & $60 \%$ & $17 \%$ & $0 \%$ \\
2030 & $45 \%$ & $5 \%$ & $30 \%$ & $20 \%$ & $0 \%$ \\
\hline
\end{tabular}

\section{Results and Analysis}

\subsection{Energy Share}

Total end use wise and source wise energy consumption data are summarized in table 2 . Total energy consumption is 5560 GJ. Fuel wood is the major source of energy contributing $70.06 \%$ of total energy and share of other sources are $14.4 \%, 13.67 \%, 1.69 \%, 0.17 \%$ and $0.01 \%$ by LPG, electricity from MHP, heat from solar, kerosene and electricity form SHS respectively.

Table 2. Commercial sector annual energy consumption pattern in GJ at year 2014.

\begin{tabular}{lllllll}
\hline End Use/Source & Cooking & Lighting & WH & OE & Total \\
\hline Electricity MHP & 39.99 & 106 & 22 & 592 & 760 \\
Electricity SHS & 0 & 0.47 & 0 & 0 & 0.5 \\
Solar Heat & 0 & 0 & 94 & 0 & 0.01 \\
Fuel Wood & 3885 & 0 & 9 & 0 & 13.7 \\
LPG & 729 & 0 & 72 & 0 & 389 \\
Kerosene & 9.6 & 0 & 0 & 0 & 800 \\
\hline
\end{tabular}

$\mathrm{WH}=$ Water Heating; $\mathrm{OE}=$ Other Electric; $\mathrm{MHP}=$ Microhydro Power; $\mathrm{SHS}=$ Solar home system

Source: HH energy survey-2014 
Table 3. End use wise energy consumption in GJ per HH.

\begin{tabular}{llllll}
\hline End Use & Cooking & Lighting & WH & OE & Total \\
\hline Energy Used & 31.53 & 0.64 & 0.61 & 3.50 & 36.26 \\
Share (\%) & 86.96 & 1.77 & 1.67 & 9.60 & 100 \\
\hline
\end{tabular}

Source: HH energy survey-2014

End use wise energy consumption summarized in table 3, which shows the maximum energy is used for cooking purpose. $83.87 \%, 10.67 \%, 3.55 \%$ and $1.92 \%$ share of total energy consumption is used for cooking, other electrics, water heating and lighting respectively.

\subsection{Energy Projection (BAU Scenario)}

The energy demand for different end use is projected using equation 1. Population elasticity values for cooking, lighting and water heating is 0.98 and for other electric is 3. Elasticity values for GDP for Cooking, lighting and water heating is 0.03 and for other electric is 0.28 [28]. The cumulative energy up to 2030 is found to be $96.5 \mathrm{TJ}$ which is equivalent to $26.8 \mathrm{GWh}$.

Table 4. Projected energy per HH in GJ, 2014 to 2030 (BAU Scenario).

\begin{tabular}{llllll}
\hline \multirow{2}{*}{ Source } & End Use & \multicolumn{2}{l}{ Year } & & \\
\cline { 3 - 6 } & & $\mathbf{2 0 1 4}$ & $\mathbf{2 0 2 0}$ & $\mathbf{2 0 2 5}$ & $\mathbf{2 0 3 0}$ \\
\hline \multirow{4}{*}{ Electricity } & Cooking & 0.235 & 0.239 & 0.239 & 0.239 \\
& Lighting & 0.624 & 0.634 & 0.634 & 0.635 \\
& WH & 0.129 & 0.132 & 0.132 & 0.132 \\
\multirow{3}{*}{ Solar Heat } & OE & 3.482 & 3.699 & 3.704 & 3.708 \\
\multirow{3}{*}{ Fuel Wood } & WH & 0.130 & 0.131 & 0.132 & 0.132 \\
& Cooking & 22.85 & 23.25 & 23.25 & 23.26 \\
LPG & WH & 0.053 & 0.054 & 0.054 & 0.054 \\
\multirow{3}{*}{ Kerosene } & Cooking & 4.288 & 4.362 & 4.363 & 4.364 \\
\hline
\end{tabular}

\subsection{Scenario Wise Energy Growth}

Figure 1 shows the scenario wise total energy growth per household from year 2014 to 2030 . In clean kitchen scenario the total energy consumption is $4892 \mathrm{GJ}(28.7 \mathrm{GJ}$ per $\mathrm{HH}$ ) in 2030 which is 14 percent less than BAU scenario. The cumulative energy up to 2030 is around $90 \mathrm{TJ}$ which is $6.6 \%$ lower than the BAU scenario. The total saving from clean kitchen scenario is found to be $6.4 \mathrm{TJ}$ which is equivalent to $1.78 \mathrm{GWh}$. On calculating using unit price of electricity of Nepal electricity at NRs 12 per $\mathrm{kWh}$ rate this accounts in total of NRs 213.6 million.

In low carbon scenario the total energy consumption is 2588 GJ (15.22 GJ per HH) in 2030 which is 54.5 percent less than BAU scenario. The cumulative energy up to 2030 is around $72 \mathrm{TJ}$ which is $25.2 \%$ lower than the BAU scenario. The total energy saving is found to be $24.4 \mathrm{TJ}$ which is equivalent to $6.76 \mathrm{GWh}$. On calculating using unit price of electricity of Nepal electricity at NRs 12 per $\mathrm{kWh}$ rate this accounts in total of NRs 811.2 million.

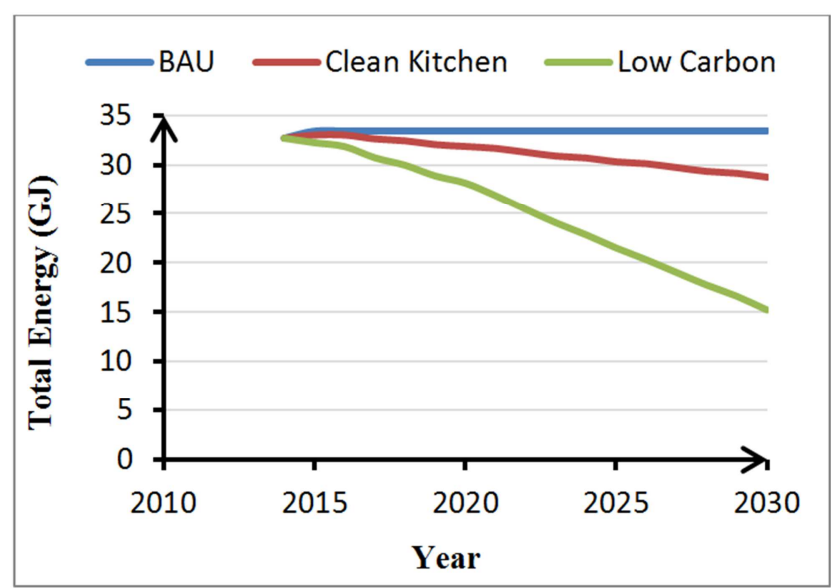

Figure 1. Scenario wise total energy growth per HH from year 2014 A.D. to 2030 A.D.

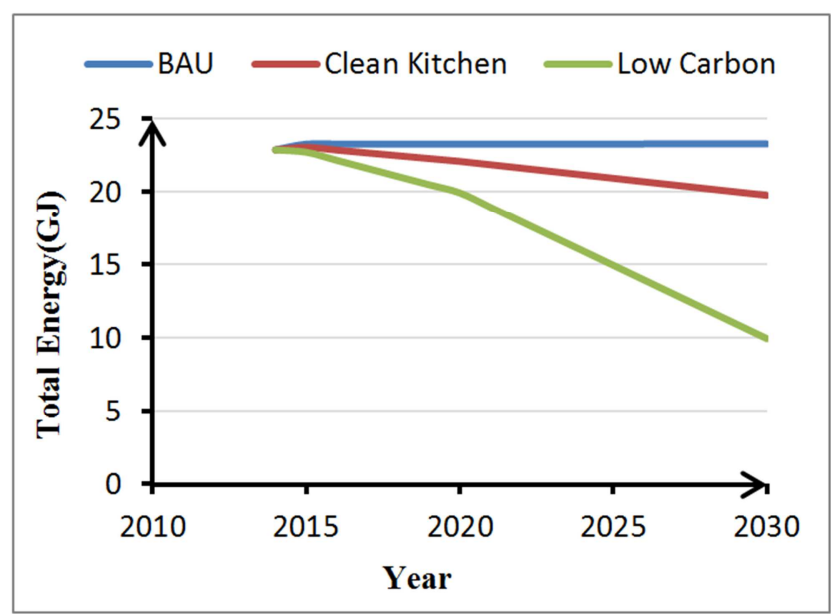

Figure 2. Total Scenario wise fuel wood energy Growth per HH from year 2014 to 2030.

The fuel wood energy consumption for the different scenario through the study period is shown in figure 2 . The fuel wood energy consumption is projected as 23.3 GJ which drops by $15 \%$ in clean kitchen and by $57 \%$ in low carbon scenario in 2030. The cumulative value of total fuel wood energy consumption and potential saving in fuel wood on different scenario is summarized on table 5. From calculation the total of 307 metric tons (1.8 tons per $\mathrm{HH}$ ) of fuel wood can be saved utilizing the clean kitchen scenario and by utilizing the low carbon scenario 1063 metric tons (6.25 tons per $\mathrm{HH}$ ) of fuel wood can be saved up to 2030 .

Table 5. Scenario of total fuel wood energy fromyear 2014 to 2030.

\begin{tabular}{llll}
\hline \multirow{2}{*}{ Scenario } & \multicolumn{2}{l}{$\begin{array}{l}\text { Cumulative Value of Fuelwood from } \\
\text { year 2014 to 2030 }\end{array}$} & $\begin{array}{l}\text { Fuelwood } \\
\text { Saving } \\
\text { (Tons) }\end{array}$ \\
\cline { 2 - 3 } & Energy (GJ) & Fuel wood (Tons) & N/A \\
\hline BAU & 67280 & 4205 & 307 \\
Clean Kitchen & 62373 & 3898 & 1063 \\
Low Carbon & 50269 & 3142 & (T) \\
\hline
\end{tabular}




\subsection{Emission Projection}

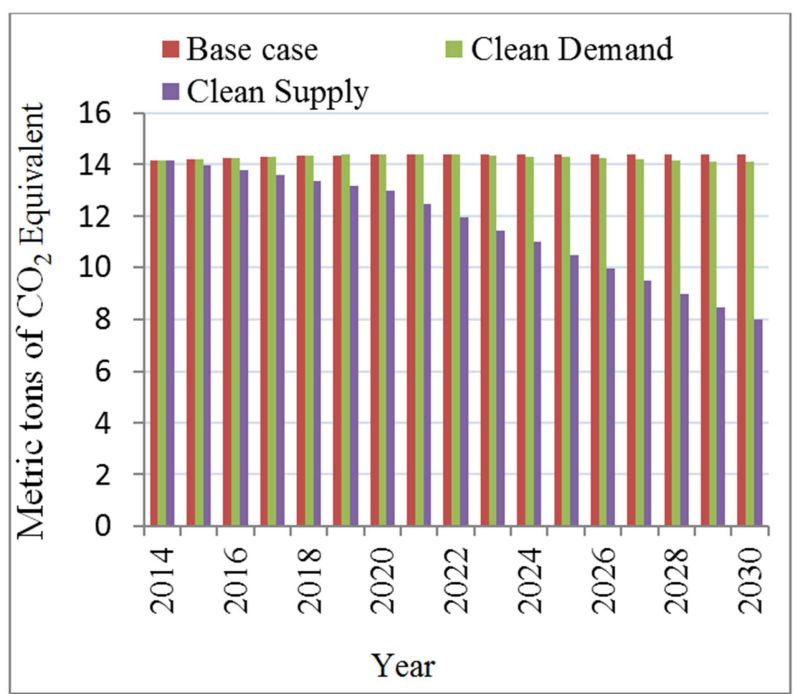

Figure 3. One hundred year GWP direct at point of emission from year 2014 to 2030in Metric tons of $\mathrm{CO}_{2}$ equivalent.

Figure 3 illustrates the One hundred year GWP direct at point of emission from year 2014 to 2030 in Metric tons of $\mathrm{CO}_{2}$ equivalent. The reduction of emission of just 2.4 percent for the year 2030 is found from the LEAP model output in clean kitchen scenario. The cumulative emission reduction from year 2014 to 2030 is 0.6 percent for the same scenario. Whereas the reduction of one hundred year GWP direct at point of emission for the year 2030 is 44.7 percent and cumulative 19.2 percent for Low carbon scenario. Which indicates the source switch is the best policy option for the significant reduction of GHW emission.

\section{Conclusion and Recommendations}

Unlike other residential sector, rural tourism area of trekking route has a different energy consumption pattern. Per household energy consumption is high in these areas and mostly depends on the number of tourist arrivals. Fuel wood is the major source of energy which is harvested from nearby forest causing depletion of forest. Since the forest in a conservation area conserves rare animals and plants, any intrusion in forest hampers the fragile ecosystem. This study shows that the dependency on fuel wood is expected to increase by 1.76 percent from year 2014 to 2030 . Consequently the local and global pollutants are expected to increase in future resulting degradation of the local and global environment. This indicates the need of policy shifting towards the promotion of utilizing clean energy resources and modern and efficient endues device. Transition from biomass energy to cleaner fuels (such as LPG, biogas and electricity for cooking), development and deployment of indigenous and innovative renewable energy technologies, and improvement of supply and demand side energy efficiency are some of the most effective measures in improving clean energy access in the rural tourism area.

Almost all household use Electricity from Micro-hydro and some use solar PV for lighting purpose. The use of electricity for lighting does not significantly reduce dependence on traditional resource, especially fuel wood resulting increase in the local and global pollutant emission. To reduce dependence on fuel wood, electricity has to be used for cooking and water heating also. Along with reducing the dependency on traditional fuels this also contributes to MHP plant factor improvement by increasing the electricity consumption time period. The result is decrease in electricity tariff.

The clean kitchen scenario and low carbon scenario analyzed in this study has a significant reduction in total energy demand of 14 percent and 54.5 percent respectively in the year 2030. The average cumulative fuel wood saving is found to be 307 metric tons ( 1.8 tons per $\mathrm{HH}$ ) for the clean kitchen scenario and 1063 metric tons (6.25 tons per $\mathrm{HH}$ ) for the low carbon scenario. The GWP emission reduction in the clean kitchen scenario is very low as compared to the low carbon scenario. This indicates energy source switch is the better option for both significant energy consumption and emission reduction in the study area. Government of Nepal and ACAP should formulate and revise different plan and policies focused on promoting clean energy technologies by giving more emphasis on promotion of the use of cleaner supply resources to protect the fragile ecosystem and maintain eco-tourism in rural tourism area.

\section{References}

[1] WECS, "National Survey of Energy Consumption and Supply Situation in Nepal," Water and Energy Commission secretariat, Kathmandu, Nepal, 2013.

[2] CBS, "Nepal Population and Housing Census: National Report," Central Bureau of Statistics, Kathmandu, Nepal, 2012.

[3] CBS, "Nepal Living Standard Survey (NLSS), Statistical Report, Vol. 1," Central Bureau of Stastistics, Kathmandu, Nepal, 2011.

[4] Becken, S., Frampton, C. \& Simmons, D., "Energy Consumption Pattern in Accommodation Sector- The New Zealand Case," Ecological Economics, Vol. 39, pp. 371-386, 2001.

[5] Gossling, S. "Global Environmental Consequence of Tourism," Global Environment Change, 2002.

[6] Warnken, J., Bradley, M., \& Guilding, C. "Exploring Methods and Practicalities of conducting Sector Wide energy consumption accounting in the tourist accommodation industry," Energy Economic, Vol. 48, pp. 125-141, 2004.

[7] Trung, D., \& Kumar, S. "Resource use and waste management in Vietnam hotel industry," Journal of Cleaner Production, Vol. 13, pp. 109-116, 2005.

[8] Nepal, Sanjay K. "Tourism-induced rural energy consumption in the Annapurna region of Nepal," Tourism Management, Vol. 29, pp. 89-100, 2008. 
[9] U, Sunlu, "Local resources and global trades: Environments and agriculture in the Mediterranean region" Environmental impacts of tourism, Vol. 57, pp. 263-270, 2003.

[10] WECS, "Energy Sector Synopsis Report 2010," Water and Energy Commission Secretariat, Kathmandu, Nepal, 2010.

[11] N. L. Panwara, S. C. Kaushikb, Surendra Kotharia, "Role of renewable energy sources in environmental protection: A review," Renewable and Sustainable Energy, Vol. 15, pp. 1513-1524, 2011

[12] AAM, Sayigh, "South South Networking and Cooperation on Renewable Energy and Sustainable Development," Renew Energ, Vol. 29 (15), pp. 2273-5, 2004.

[13] Y. P. Cai, G. H. Huang, Q. Tan, Z. F. Yang, "Planning of Community- scale Renewable Energy Managemant System in a mixed and stochastic and fuzzy environment,"Renew Energ, Vol. 34, pp. 1833-1847, 2009.

[14] WECS, "Energy Synopsis Report: 2006," Water and Energy Commission Secretariat (WECS), Kathmandu, Nepal, 2006.

[15] NPC, "The Fifth plan (1975-80)," National Planning Commission, Kathmandu, Nepal, 1975.

[16] NPC, "The Tenth plan (2002-2007)," National Planning Commission, Kathmandu, Nepal, 2002.

[17] NPC, "The Thirteen plan (2013-2016)," National Planning Commission, Kathmandu, Nepal, 2013.

[18] MOE, "Rural Energy Policy 2006," Ministry of Environment, Kathmandu, Nepal, 2006.

[19] Ministry of Population and Environment, "Renewable Energy Subsidy Policy, 2073 BS," Ministry of Population and Environment, Kathmandu, Nepal, 2016.

[20] SEI, "Long-range Energy Alternatives Planning System: User Guide for Version 2011," Stockholm Environment Institute, Somerville, USA, 2011.

[21] D. Connolly, H. Lund, B. V. Mathiesen, M. Leahy, "A review of computer tools for analysing the integration of renewable energy into various energy systems," Applied Energ, Vol. 87, pp. 1059-1082, 2010.
[22] OECD/IEA, "Energy and Climate Change, World Energy Outlook Special Report," International Energy Agency (IEA), Paris, France, 2015.

[23] AEPC, "Solar and Wind Energy Resource Assessment (SWERA), Final Report (GIS Part)," United Nation Environment Programme, Global Environment Facility, Kathmandu, Nepal, 2008.

[24] Kaski, DDC, "District Profile, kaski (Nepali Version)," District Development Committee, Kaski, Nepal, 2010.

[25] Bhattacharyya, Dr. Subhes C., "Concepts, Issues, Markets and Governance," Energy Economics, 2011. 978-0-85729-267-4.

[26] IPCC, "Guidelines for National Greenhouse gas inventories, IPCC National Greenhouse Gas Inventories Program, Intergovernmental Panel of Climate Change,"Institute for Global Environment Strategies, Japan, 2006.

[27] Kamal, Rijal, "Renewable Energy Policy Options for Mountain Communities: Experiences from China, India, Nepal and Pakistan," Renewable Energy, Energy Efficiency, Policy and the Environment, Vol. 16, pp. 1138-1142, 1999.

[28] Shakya Shree Raj, Ram M. Shrestha, "Transport sector electrification in a hydropower resource rich developing country: Energy security, environmental and climate change co-benefits, "Energy for Sustainable devlopment, vol. 15, pp. 147-159, 2011.

[29] Ministry of Culture, Tourism \& Civil Aviation, "Nepal Tourism Statistics 2012," Ministry of Culture, Tourism \& Civil Aviation, Planning \& Evaluation Division, Statistical Section, Singha Durbar, Kathmandu, Nepal, 2013.

[30] MoF, "Economic Survey of Fiscal Year 2013/14," Ministry of Finance, Kathmandu, Nepal, 2014.

[31] R. B. Thapa, R. M. Shrestha, "Metallic Improved Cook Stoves Dissemination in Mountain Region of Nepal: Experience, Financial Viability, Opportunity \& Challenges,"Rentech Symposium Compendium, Vol. 3, 2013. 